\title{
EPIDURAL BLOCKADE AND CIRCULATING CATECHOL AMINE LEVELS IN A CHILD WITH PHAEOCFIROMOCYTOMA
}

\author{
P. R Bromage, M B., B S, F F A R C S , ${ }^{1}$ and \\ R A Millar, MD, F F A R C ${ }^{2}$
}

THIS REPORT concerns the management of a child in whom transperitoneal excision of an adrenal medullary tumour was performed under a combination of continuous epıdural blockade and supplementary light general anaesthesia. The epidural block provided abdominal relaxation with operative and postoperative analgesia, while the upper level of analgesia was carried high enough to ensure total sympathetc blockade An attempt was made to assess the effects of this anaesthetic technique on the circulating blood levels of adrenalin and noradrenalin during operation. The data obtaned mcludes that from analysis of pre and postoperative plasma samples and of adrenal venous blood before tumour removal. The findings will be presented and discussed here

\section{CASE Report}

This 8-year-old boy (height $47 \mathrm{in}$, weight $47 \mathrm{lb}$ ) was admitted to hospital with a 7 -day history of paroxysmal headache, cold sweats, and three convulsıve seizures Blood pressure was $195 / 170$, heart 'rate 160, cerebrospinal flud and unne examinations were normal, $B \mathrm{M} \mathrm{R}$, was +22 per cent, sugar tolerance was dimmıshed

A phaeochromocytoma was diagnosed and preoperative treatment with phentolamine ("Regitine") started forthwith Oral doses of $50 \mathrm{mg}$ three hourly were required to reduce and maintan blood pressure at about 140\% Samples of penpheral venous blood were withdrawn for analysis of plasma adrenalin and noradrenalin concentration, five days and one day preoperatively The results are illustrated in Table-I

\section{Anaesthetrc Management}

The last oral dose of phentolamine (50 thg.) was given at $300 \mathrm{~A} \mathrm{M}$ on the day of operation, the effects were expected to last for about four hours Between 7.15 and $8.15 \mathrm{~A} \mathrm{M.} 3 \mathrm{mg}$ of the drug were given by slow intravenous infusion, but none thereafter At 8.00 A.M. the child was brought to the operating room asleep, following heavy premedication with pentobarbital $60 \mathrm{mg}$ two and a half hours before, and Demerol $25 \mathrm{mg}$ with hyoscine gr. 1/150 one hour before. Light anaesthesia was induced with nitrous oxide, oxygen, and thiopental An epidural catheter was then inserted between the first and second lumbar spines It was estımated that $24 \mathrm{ml}$. of Xylocaine solution would be required to produce epidural analgesia up to the segmental level $T_{1} C_{8}$, with total sympathetic blockade (1). Twenty minutes after injection of $19 \mathrm{ml}$. of 1.4 per cent Xylocaine, skm analgesia was present to $T_{4}$, the block was therefore extended by injectıng a further $10 \mathrm{ml}$. In the meantime the trachea was untubated and a gastric tube

${ }_{1}$ McGill University and Dept of Anaesthesia, Royal Victona Hospital

2McGill University and Dept of Anaesthesia, Montreal Neurological Institute 
passed durnng brief succinylcholıne paralysis ( $20 \mathrm{mg}$.). General anaesthesia was continued with nitrous oxide and.oxygen in the proportion 5.3, apnoèa being mauntained by manual hyperventılation.

Several blood samples were withdrawn durnng the preparatory period before surgery (Samples 1-3, Table I and Fig 1) Sample 4 was withdrawn as the surgical incision was made, fifty minutes after the first epidural injection of Xylocaine.

TABLE I

Plasma Catechol Amine levels

\begin{tabular}{|c|c|c|c|}
\hline Sample & Period & $\begin{array}{l}\text { Noradrenalın } \\
\mu \mathrm{g} / \mathrm{L}\end{array}$ & $\begin{array}{l}\text { Adrenalın } \\
\mu \mathrm{g} / \mathrm{L}\end{array}$ \\
\hline Preoperative & $\begin{array}{l}5 \text { days before operation } \\
1 \text { day before operation }\end{array}$ & 144 & $\begin{array}{ll}2 & 6 \\
5 & 9\end{array}$ \\
\hline Sample I & Immediately after induction of a naesthesia & 508 & - \\
\hline Sample II & 12 minutes after induction & 653 & - \\
\hline Sample III & $\begin{array}{l}30 \text { minutes after inducing epidural block } \\
\text { to } T_{4}\end{array}$ & 606 & - \\
\hline Sample IV & $\begin{array}{l}10 \text { minutes af ter extending epidural block } \\
\text { to } C_{8}\end{array}$ & 314 & - \\
\hline $\begin{array}{l}\text { Sample V } \\
\text { Sample VI } \\
\text { Postoperative } \\
\text { Excised tumour } \\
\text { (assayed by Dr } \\
\text { B G Benfey) }\end{array}$ & $\begin{array}{l}\text { During manipulation of tumour } \\
\text { From adrenal vem before tumour removal } \\
6 \text { days after operation }\end{array}$ & $\begin{array}{c}957 \\
602 \stackrel{2}{2} \mu \mathrm{g} / \mathrm{ml} \\
042 \mu \mathrm{g} / \mathrm{L} \\
1470 \mu \mathrm{g} / \mathrm{g}\end{array}$ & \begin{tabular}{ll} 
& \multicolumn{1}{c}{-} \\
0 & $1 \overline{\mu g} / \mathrm{ml}$ \\
4 & $42^{\mu g} / \mathrm{L}$ \\
4 & $14 \mu \mathrm{g} / \mathrm{gm}$
\end{tabular} \\
\hline
\end{tabular}

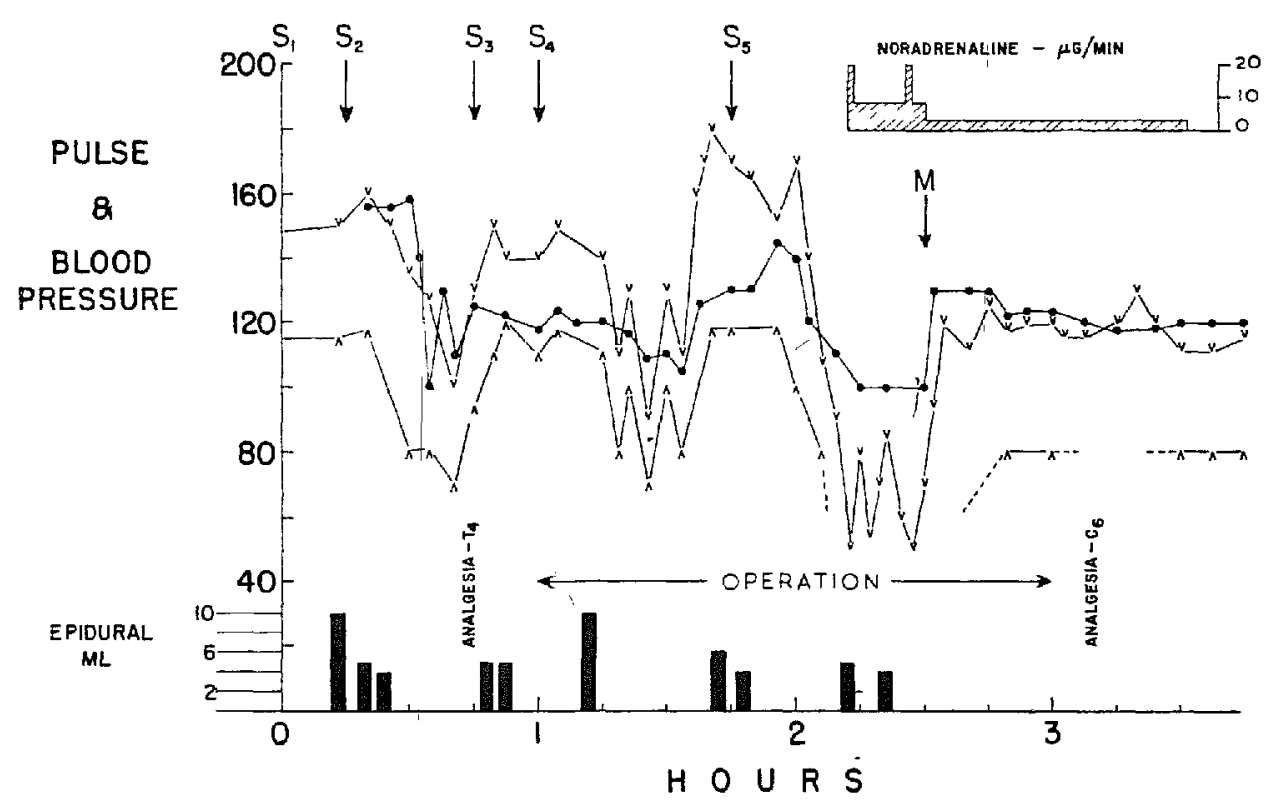

FIGURE 1. Anaesthetic chart of 8-year-old boy undergoing excision of phaeochromocytoma. Epidural injections of $14 \%$ Xylocaine are shown as vertical columns Samples of penpheral venous blood were taken at $S_{1}, S_{2}, S_{3}, S_{4}, S_{5}$ Methedrine $10 \mathrm{mg}$. was given intravenously at $M$.

A left adrenal medullary tumour weighing 26 grams was removed through a transverse abdominal incision. The operative course was smooth, ápart from two 
periods when the blood pressure changed sharply (see Fig. 1) Durmg manrpulation of the tumour blood pressure increased to $185 / 125 \mathrm{~mm}$, and the peripheral venous plasma concentration of noradrenalin rose to the highest estimated level, 95 microg. per litre (Sample V', Table I).

No adrenalm could be detected in any of the five blood samples withdrawn during anaesthesia. The hypotension which occurred following removal of the tumour was partly corrected by an infusion of noradrenalm (2-20 $\mu \mathrm{g}$. per minute), supported later by methyl amphetamine methedrine $10 \mathrm{mg}$., which produced a sharp increase to normotensive levels. Thereafter blood pressure remained at about $125 / 85$ with an infusion rate of $2-3 \mu \mathrm{g}$. of noradrenalin per minute.

The patient was awake as the last stitches were being tied, when analgesia was present to the level of the sixth|cervical segment. The noradrenalin infusion was stopped one hour postoperatively, no further pressor drugs being required. Postoperative analgesia was maintained for the next twelve hours by injecting $10 \mathrm{ml}$. of 08 per cent Xylocame through the epidural catheter every 90 minutes.

The subsequent postoperative course was smooth Heart rate was 160 per minute for 15 hours, 140 per minute for the next 8 hour period, finally declining to $90-110$ over the next 3 days. A sample of perrpheral venous blood withdrawn on the sixth day after operation showed "normal" low values of noradrenalın and adrenalin (Table I). The patient was discharged in excellent condition, with a blood pressure of $120 / 80$, on the eleventh postoperative day

\section{Discussion}

The fluorimetric method used in this study for plasma catechol amine estimations enables adrenalin and noradrenalin to be determined separately (2) The peripheral venous plasma levels in normal resting subjects are less than $05 \mu \mathrm{g}$. per litre for each amine. Analysis of the two preoperative samples withdrawn from this patient (total circulating catechol amines 170 and $160 \mu \mathrm{g}$. per htre respectively), and the findings from a case previously reported (3) illustrate the value of plasma estimations in confirming the diagnosis of suspected adrenal medullary tumours.

A study of the literature suggests that choice of anaesthetic technique for patients with phaeochromocytoma is usually based on individual experience and preference, rather than on a firm foundation of applied pharmacology. Many agents have been successfully employed, -against any one of which some theoretical objections can be raised. Thus, although ether has been used extensively and successfully $(4,5)$, it is nevertheless a powerful adrenal medullary stimulant in animals (6), and might be expected to increase circulating catechol amines to undesirably high levels. Cyclopropane incurs a serious risk of ventricular arrhythmias in the presence of high concentrations of adrenalin or noradrenalin (7), and yet it has been used successfully (8). Spinal block has its advocates $(9,10)$, although interference with circulatory control might appear to make it a dangerous choice in the presence of phaeochromocytoma $(4,5)$. Thus, practical 
success has been obtamed with a variety of methods, each of which could be labelled as theoretically objectionable, confirming the statement of Apgar and Papper that "the relationship between mortality and morbidity and anaesthetic agent or technique cannot be clearly defined from the data available" (4).

The formation, methylation and discharge of catechol amines in the normal adrenal medulla may be intmately related to splanchnic nervous control (11), but factors governing the activity of adrenal medullary tumours are poorly understood. It is usually assumed that the discharge of pressor amines from a phaeochromocytoma is dependent on mechanical or humoral factors rather than direct nervous control through the splanchnic outllow. In this patient, the relative depression of circulating noradienalin to the lowest operative level at Sample 4 mąy have been due to the 50-minute period of induced sympathetic blockade. Nevertheless, the persistently high levels of noradrenalin seem to imply that efferent nervous control of the adrenal medullary tumour was relatively unimportant in this case. The obvious influence of mechanical compression is reflected in the highest circulating noradrenalin levels occurring during manipulation of the tumour area. This is an expected finding, which has been noted by one of us in a previous case (3). The enormous concentration of noradrenalin in adrenal venous blood just before removal of the tumour (600 $\mu \mathrm{g}$ per millilitre) illustrates the extraordinary tolerance shown by these patients to blood levels far beyond the physiological rangé.

The physiological meaning of such high levels is difficult to determine, for above a certain limit additional increases in pressor amine concentration fail to produce further significant rises of blood pressure. It has been shown that the response of blood pressure to infused adrenalm or noradrenalin follows a hyperbolic curve, so that at a certain blood concentration the arterial pressure curve flattens out to a maximum beyond which further doses of pressor amine produce little effect (12) The crrculating noradrenalin concentrations found at operation in this patient were almost certannly well above this level Moreover, high circulatng levels of adrenalın or noradrenalin can produce ganglionic blockade and vasodilation $(13,14,15)$, so that with concentrations of this order it is difficult to assess the significance of blood pressure in relation to changing levels of noradrenalin. Thus any attempt to relate the effect of a particular anaesthetic technique to levels of circulating catechol amines so far beyond the physiological range could be of academic rather than practical importance.

In spite of greatly increased plasma concentrations of noradrenalin during operation, epidural blockade was accompanied by levels of blood pressure lower than those observed in the preoperative period before phentolamine was started. In this case, therefore, total sympathetic blockade did not appear to produce the augmentation of pressor response to circulating vasoactive amines that has been reported previously $(16,17)$.

From a clinical viewpoint the operative and postoperative course in this child was impressively.smooth. The use of continuous epidural blockade, in conjunction with light general anaesthesia, is recommended as a suitable anaesthetic technique for patients with adrenal medullary tumours. 
We are grateful to $\mathrm{Dr} A \mathrm{~B}$ Noble for his assistance in the anaesthetic management of this case.

\section{RÉSUMÉ}

En enlevant un phéochromocytoma du cóté gauche, chez un enfant de huit ans, on a fait dısparaître une hypertension consıclérable Comme mode d'anesthésie pour permettre cette opération, on a associé du pentothal, du protoxyde d'azote et de l'oxygène, et une analgésie épidurale continue atteignant la hutième cerkicale L'état du malade, au cours de l'opération et des suites opératoires, est demeuré satısfaisant

Avant, pendant et après l'opération, nous avoris falt le dosage des catéchol ammes plasmatiques pour juger de l'mfluence d'un blocage sympathque total sụ les quantités de noradrénalne corculante Après l'mduction de l'anesthésie générale, en comparaison avec les taux préopératorres, la quantité de noradrénaline circulante a quadruplé et même, après le blocage sympathique total, lạ concentration des catéchol ammes sérıques est demeurée double de ce qu'elle était avant l'opération. Il nous a semblé que, au cours de l'opération, de façon générale, la tension artérnelle est demeurée indépendante du taux absolu de catéchol amines, car elle est restée plus basse qu'on aurat pu s'attẹndre de la trouver étant donné la haute concentration de noradrénalme circulante qui existart Toutefors, les augmentations et les chutes de tension artérnelle ont suivi, en général, les modıfications de concentration de catéchol ammes Nous faisons l'interprétation de ces résultats.

\section{REFERENCES}

1 Bromage, P R Spinal Epidural Anal zesia Edinburgh Livingstone (1954)

2 Millar, R A, \& Benfey, B G T.e Fluormetric Estimation of Adrenaline and Noradrenalıne during Haemorrhagic Hypotension Brit J Anaesth 30158 (1958)

3. Benfey, B G, \& Millar, R A Catechol Atnines in Blood, Urine, and Tumour in a Patient with Phaeochromocytoma Canad M A T 77 701 (1957)

4 Apgar, Vै, \& PApper, E M Pheochromocytoma Anesthetic Management during Surgical Removal Arch Surg 62634 (1950)

5 Thomson, J E, \& Arrowood, J G. Pheochromocytoma Surgical and Anesthetic Management Anesthesiology 15658 (1954)

6 Watrs, D T Epinephrine in Circulating Blood during Ether Anesthesia J Pharmacol 114203 (1955)

7 Meek, W J, Hathaway, H R, \& Orth, O S Effects of 'Ether, Chloroform and Cyclopropane on Cardiac Automaticity J Pharmacol 61 240 (19.37)

8 Hrman, A, \& Mencher, W H Pheochromocytoma of the Adrenal Gland J Urol 49 $755(1943)$

9. Espersen, T, \& Dahl-Iversen, E The Clinical Picture and Treatment of Phaeochromocytomas of the Suprarenal Acta chir Scandinav 94271 (1946)

10 De Courcy, J L, \& De Courcy, C B Pheochromocytoma and the General Practitioner Cincinnatı Barclay Newman (1952). 
11. Holland, W. C., \& Schumani, H. J. Formation of Catechol Amines during Splanchnic Stimulation of the Adrenal Gland of the Cat. Brit. J. Pharmacol 11: 449 (1956).

12. Brown, R. V. Dose Response Curve for the Blood Pressure Effects produced by Graded Doses of 1-epinephrine with Commercial Epinephrine and 1-Norepinephrine. J. Pharmacol. 105: 139 (1952).

13. Marrazzr, A. S. Electrical Studies on the Pharmacology of Autonomic synapses. II. The Action of a Sympathomimetic Drug (epinephrine) on Sympathetic Ganglia. J. Pharmacol. 65: 395 (1939).

14. Bulbring, E., \& BurN, J, H. An Action of Adrenaline on Transmission in Sympathetic Ganglia which May Play a Part in Shock. J. Physiol. 101: 289 (1942).

15. Hutcheon, D. E. D.Ph. thesis, Oxford (1950), quoted by Burn, J. H. Brit. J. Anaesth. 28: 459 (1956).

16. Page, I. H., \& TAYLoR, R. D. Augmentation of Vasoactive Substances. Circulation 1: $1233(1950)$.

17. Bromage, P. R. Comparison of Vasoactive Drugs in Man. Brit. M. J. 2: 72 (1953). 